\title{
Nutrient Enhancement of Ground Sago (Metroxylon sagu Rottboll) Pith by Solid State Fermentation With Rhizopus oligosporus for Poultry Feed
}

\author{
Azilah Ab Jalil ${ }^{1}$, Norhani Abdullah ${ }^{1,2}$, Abdul Razak Alimon ${ }^{1,3}$ \& Suraini Abd-Aziz ${ }^{4}$ \\ ${ }^{1}$ Laboratory of Animal Production, Institute of Tropical Agriculture, Universiti Putra Malaysia, Selangor, \\ Malaysia \\ ${ }^{2}$ Department of Biochemistry, Faculty of Biotechnology \& Biomolecular Sciences, Universiti Putra Malaysia, \\ Selangor, Malaysia \\ ${ }^{3}$ Department of Animal Science, Faculty of Agriculture, Universiti Putra Malaysia, Selangor, Malaysia \\ ${ }^{4}$ Department of Bioprocess Technology, Faculty of Biotechnology \& Biomolecular Sciences, Universiti Putra \\ Malaysia \\ Correspondence: Azilah Ab Jalil, Laboratory of Animal Production, Institute of Tropical Agriculture, Universiti \\ Putra Malaysia, 43400 UPM Serdang, Selangor, Malaysia. Tel: 603-8947-1172. Fax: 603-8938-1612. E-mail: \\ azilahj@upm.edu.my
}

Received: October 9, 2014 Accepted: December 3, 2014 Online Published: December 5, 2014

doi:10.5539/jfr.v4n2p1 URL: http://dx.doi.org/10.5539/jfr.v4n2p1

\begin{abstract}
Utilization of ground sago pith (GSP) as poultry feed ingredient is limited due to its high fibre content and negligible amount of protein. Hence, to enhance its utilization in poultry feed formulations, proper treatment method is necessary. This study was aimed to improve the nutritive value of GSP through solid state fermentation (SSF) using Rhizopus microspores var. oligosporus isolated from fermented cooked soybean seeds (local name tempeh). Fermentation of GSP was first conducted in $500 \mathrm{ml}$ Erlenmeyer flasks to determine the optimized conditions. The substrate was prepared by mixing $50 \mathrm{~g}$ of GSP with $50 \mathrm{ml}$ mineral solution and sterilized by autoclaving. The autoclaved GSP was inoculated with $5 \mathrm{ml}$ of $R$. oligosporus spore suspension $\left(1 \times 10^{6} \mathrm{spore} / \mathrm{mL}\right)$. Four factors were investigated; moisture levels $(35,45,55,65$ and $75 \mathrm{ml} \mathrm{liquid} / 50 \mathrm{~g}$ substrate), $\mathrm{pH}$ values (4.5, 5, $5.5,6,6.5,7$ and 7.5), incubation temperatures [ambient temperature $(28 \pm 2), 30,32.5,35$ and $37.5^{\circ} \mathrm{C}$ ] and inorganic nitrogen (ammonium sulphate, ammonium phosphate, ammonium carbonate, ammonium nitrate, ammonium chloride and ammonium molybdate) sources at $1 \%(\mathrm{w} / \mathrm{v})$ concentrations. Fermentation was conducted for 3 days and the parameters measured were reducing sugar, soluble protein and hydrolytic enzyme activities. The optimized conditions in the flask system were moisture level of $55 \mathrm{ml}$ liquid/50 g substrate, citrate buffer $\mathrm{pH} 6.0$, incubation temperature $30^{\circ} \mathrm{C}$ and ammonium sulphate as the inorganic nitrogen source. A time course study for 7 days under optimized conditions showed that the reducing sugar reached maximum from $15.7 \pm 0.5$ to $183.8 \pm 22.6$ $\mathrm{mg} / \mathrm{g}(\mathrm{dmb})$ at 1.5 days and the soluble protein increased from $9.5 \pm 0.5$ to $11.4 \pm 0.7 \mu \mathrm{g} / \mathrm{g}$ (dmb) at the end of fermentation period. Amylase and CMCase activities were maximum at 3 days of fermentation; $3.580 .73 \pm$ and $4.44 \pm 1.50 \mathrm{U} / \mathrm{mg}$ protein, respectively but FPase activities did not show apparent changes during the time course study. Using the optimized condition, scaling up in a horizontal drum laboratory fermenter was conducted using 3 $\mathrm{kg}$ of GSP in the presence of air at $4 \mathrm{~L} / \mathrm{min}$ flow rate. The nutrient composition of fermented GSP produced in the fermenter was $89.1 \%$ dry matter, $3.4 \%$ crude protein, $5.5 \%$ crude fiber, $6.3 \%$ ash and $3495 \mathrm{kcal} / \mathrm{kg}$ gross energy as compared to $88.2 \%$ dry matter, $1.6 \%$ crude protein, $6.0 \%$ crude fiber, $5.3 \%$ ash and $3608 \mathrm{kcal} / \mathrm{kg}$ gross energy for untreated GSP. Solid state fermentation by $R$. oligosporus had increased the reducing sugar by $61 \%$, glucose and fructose by more than $100 \%$, soluble protein by $1 \%$ and amino acids by 1.5 to $38.2 \%$. Cysteine which was undetected in the unfermented GSP was produced during the fermentation at a concentration of $222 \mathrm{ppm}$. The other amino acids were increased by $1.5 \%$ (arginine), $2.1 \%$ (glutamic acid), $16.2 \%$ (isoleucine), $16.5 \%$ (leucine), $6.2 \%$ (phenylalanine), $25.7 \%$ (proline), $38.2 \%$ (serine), $27.3 \%$ (threonine)and $5.7 \%$ (tyrosine). The results showed that the nutritive value of GSP was enhanced by solid state fermentation with $R$. oligosporus.
\end{abstract}

Key words: solid state fermentation, ground sago pith, Rhizopus oligosporus, nutrient enhancement 


\section{Introduction}

The cost of feed ingredients contributed to a large proportion of the total cost in poultry industry. The increasing cost of some of the feed ingredients used in the formulations especially the cereal grains as a source of energy, has stimulated research in the use of alternative feed resources. Local feedstuffs such as palm kernel cake, rice bran, cassava meal and sago products have been identified as alternative feeds in Malaysia to partially substitute feeds like corn and soybean for poultry.

Sago palms, Metroxylon sagu (Rottboll) belongs to the Palmae family and is an important starch producing crop distributed in the South Pacific Islands, extending through Melanesia into Thailand, Malaysia, Indonesia and the Papua New Guinea (Karim et al., 2008). It grows well in humid tropical lowland areas and can tolerate wet growing conditions, including peat swamps. The biggest sago growing area in Malaysia is in the state of Sarawak with the export revenue of about 45,300 metric tons of food-grade sago starch earning about RM40.4 million in 2005 (Dept.of Statistics Malaysia).

The sago starch can be processed to various products like sago pearls, as a substitute for modified corn starch in the production of monosodium glutamate and fructose syrup for non-alcoholic drinks when combine with other starches. Other products derived from sago starch such as modified starch, cyclodextrins and ethanol have a significant commercial value (Singhal et al., 2008). Ground sago pith (GSP) is another products obtained from the pith of the sago palmsafter removal of the lignified bark, undergoing size reduction, dried and ground to fine particles.

Chemical analysis showed that dry sago pith contain 722 to $751 \mathrm{~g} / \mathrm{kg}$ starch, 66 to $74 \mathrm{~g} / \mathrm{kg}$ cellulose, 36 to $40 \mathrm{~g} / \mathrm{kg}$ hemicelluloses, 11 to $12 \mathrm{~g} / \mathrm{kg}$ crude protein and 35 to $66 \mathrm{~g} / \mathrm{kg}$ ash (Yahya et al., 2011). The GSP may be grouped into an energy feed based on an international classification standard (Harris et al., 1968). The use of feed sources containing highly fermentable carbohydrate such as GSP is important in optimizing livestock production in Malaysia. However, utilization of GSP as a feedstuff is limited due to its high moisture content, fibrous components and negligible amount of protein.

In order to improve its utilization in poultry feed formulations, enhancement of the nutritive value through proper processing methods is necessary. The microbiological method through solid state fermentation (SSF) is one of the strategies to improve the nutritive value of animal feed as the fermentation enhances the bioavailability of nutrients (Hotz \& Gibson, 2007). Conversion through microbial SSF has been reported in starch based substrate such as soybean meal (Teng et al., 2012; Chen et al., 2013), rice bran (Schmidt \& Furlong, 2012) and starch extracts from soybean flour (Olanipekun et al.,2009). Filamentous fungi such as $R$. oligosporus is commonly used in SSF for the production of food and feed because they do not produce any toxic substances and has long history in the production of tempeh, an Asian fermented food made of cooked soybean (Nout \& Kiers, 2005).

Hence, the objective of the present study was to enhance the nutritive value of GSP by SSF with $R$. oligosporus locally isolated from fermented cooked soybean seeds (tempeh).

\section{Materials and Methods}

\subsection{Fungal Culture And Preparation of Inoculum}

Fungal culture was isolated from tempeh and identified by morphological characteristics and molecular techniques. It was identified as Rhizopus microspores var. oligosporus in the phylum of Zygomycetes. The culture grown on potato-dextrose agar (PDA) plates at $30{ }^{\circ} \mathrm{C}$ for 6 to 7 days was used to prepare the inoculum. The spores were harvested by adding $10 \mathrm{ml}$ of $0.01 \%$ Tween- 80 solution to dislodge them by using a glass rod under aseptic conditions. The spores were transferred into a $500 \mathrm{ml}$ sterilized bottles by filtering with glass wool. The glass wool was folded into seven layers to provide filters with pore size of approximately $0.5 \mathrm{~mm}$. Inoculum density was determined by counting using a haemacytometer and adjusted to a concentration of $1 \times 10^{6} \mathrm{spore} / \mathrm{ml}$. Five milliters of inoculum were used to inoculate each fermentation flask or $300 \mathrm{ml}$ for fermentation in a horizontal drum laboratory fermenter.

\subsection{Ground Sago Pith}

Ground sago pith (GSP) was prepared by first removing the lignified bark of the sago logs and chopping the pith to small pieces of approximately 5 to $10 \mathrm{~cm}$ using a mechanical chopper at the factory (Batu Pahat, Johor, Malaysia). The sago pieces were dried in a solar house dryer $\left(38 \pm 5{ }^{\circ} \mathrm{C}\right)$ at the Malaysian Agricultural Research and Development Institute (MARDI) for 2 weeks. The dried sago pith with moisture content of 10 to $11 \%$, were shred to reduce the size to around 0.5 to $1 \mathrm{~cm}$. The dried pith was later ground to a fine powder $(0.2$ to $5.5 \mathrm{~mm}$ size $)$ by using a hammer mill grinder and stored in air-tight container at room temperature. Five sago logs of approximately 
$100 \mathrm{~cm}$ (length) $\times 45$ to $48 \mathrm{~cm}$ (diameters) were used to obtain dried GSP of about $40 \mathrm{~kg}$. The bulk density of the GSP was $264.39 \pm 9.02 \mathrm{~g} / \mathrm{L}$ as measured using a modified method by Grossman and Reinsch (2002).

\subsection{Fermentation in $500 \mathrm{ml}$ Erlenmeyer Flask}

Fermentation of GSP was first conducted in $500 \mathrm{ml}$ flasks to determine the optimized conditions by the conventional method. In each set of fermentation, one factor was investigated by varying the levels while keeping the other factors at constant values. Four factors were investigated; moisture levels $(35,45,55,65$ and $75 \mathrm{ml}$ liquid/50 g substrate), $\mathrm{pH}$ values $(4.5,5,5.5,6,6.5,7$ and 7.5$)$, incubation temperatures [ambient temperature (28 \pm 2 ), 30, 32.5, 35 and $37.5{ }^{\circ} \mathrm{C}$ ] and inorganic nitrogen from various sources (ammonium sulphate $\left(\mathrm{NH}_{4}\right)_{2} \mathrm{SO}_{4}$, ammonium phosphate $\mathrm{NH}_{4} \mathrm{PO}_{4}$, ammonium carbonate $\mathrm{NH}_{4} \mathrm{CO}_{3}$, ammonium nitrate $\mathrm{NH}_{4} \mathrm{NO}_{3}$, ammonium chloride $\mathrm{NH}_{4} \mathrm{Cl}$ and ammonium molybdate $\left.\mathrm{NH}_{4} \mathrm{MO}_{3}\right)$ at $1 \%(\mathrm{w} / \mathrm{v})$ concentrations.

The substrate was prepared by mixing $50 \mathrm{~g}$ of GSP with $50 \mathrm{ml}$ mineral solution [0.01M citrate buffer $\mathrm{pH} 6.0$ containing $0.01 \%(\mathrm{w} / \mathrm{v}) \mathrm{KH}_{2} \mathrm{PO}_{4}, 0.01 \%(\mathrm{w} / \mathrm{v}) \mathrm{MgSO}_{4} .7 \mathrm{H}_{2} \mathrm{O}$ and $1 \%(\mathrm{w} / \mathrm{v})$ of $\left(\mathrm{NH}_{4}\right)_{2} \mathrm{SO}_{4}$ as nitrogen source] in $500 \mathrm{ml}$ Erlenmeyer flask. The flask was plugged with cotton wool wrapped with gauze, covered with aluminium foil and autoclaved at $121{ }^{\circ} \mathrm{C}$ for 20 minutes. Each flask was inoculated with $5 \mathrm{ml}$ of $1 \times 10^{6}$ spore/ml spore of $R$. oligosporus. The fermentation was performed for 3 days at $30{ }^{\circ} \mathrm{C}$ in an incubator (Memmert INE 700, Germany) with interior dimensions of $(1040 \times 500 \times 800) \mathrm{mm}$. The flasks containing GSP were prepared in triplicates for each fermentation conditions. Parameters measured were reducing sugar, soluble protein, amylase, filterpaperase (FPase) and carboxymethylcellulase (CMCase). The time course study for the fermentation at optimized conditions was conducted for 7 days. Samples were collected every 12 hours for measurement of $\mathrm{pH}$, temperature, reducing sugar, soluble protein and hydrolytic enzyme activities.

\subsection{Fermentation in Horizontal Drum Fermenter}

Fermentation was performed in a stainless steel horizontal drum fermenter with inner dimensions of $210 \mathrm{~mm} \times 178$ $\mathrm{mm}$ (length $\times$ diameter). The total volume is approximately $5 \mathrm{~L}$ (Biosys SF-20 rotary-shaft SSF, Malaysia). The drum is equipped with water jacket, inlet for water supply, motor system, heater, air compressor, airflow meter, air filter, an opening on top of the drum, an opening at the rear side of the drum and related control valves. The system is connected to a controller to regulate functions of mixing, aeration and the fermenter temperature. The top opening is covered with glass for visual inspection during fermentation. Both openings at the top and the side of the drum have water-tight seals that prevent outside contamination or rapid moisture lost from the fermented material. Air was supplied through air filters to provide sterilised air blown across the top of the substrate bed. The excess gas will escape through the outlet valve. The fermenter temperature is controlled by circulation of cooling water through the outer jacket of the drum. The substrate humidity was measured by a relative humidity (RH) probe and the substrate temperature was measured by a temperature probe.

Substrate for the fermenter was prepared by mixing $3 \mathrm{~kg}$ of GSP with mineral solution as in the flask experiment. Then, the substrate was divided into approximately $200 \mathrm{~g}$ in bags, autoclaved and cooled to room temperature. The inner surface of the fermenter was disinfected by $70 \%$ alcohol before loading the substrate. Fermentation was conducted using optimized conditions previously determined from the flasks experiment. The fermentation conditions wereset at $30^{\circ} \mathrm{C}$ in unmixed mode and the incoming airflow of $4 \mathrm{~L} / \mathrm{min}$ for 44 hours fermentation.

Fungal growth during fermentation was monitored by visual inspection and the fermentation was stopped when the mycelia fully covered the substrate. At the end of fermentation, the product was removed through the rear side opening and manually mixed and dried at $50{ }^{\circ} \mathrm{C}$ in a hot air oven for 4 days. The product was analysed for reducing sugar, soluble protein, proximate compositions and hydrolytic enzyme activities.

\subsection{Analytical Methods}

Dried samples of untreated and fermented GSP were determined for dry matter, ash, crude protein, crude fiber and gross energy according to standard methods (AOAC, 2000). Analysis of reducing sugar and soluble protein was conducted using culture filtrate. The filtrate was prepared by mixing $5 \mathrm{~g}$ of fermented GSP with $50 \mathrm{ml}$ of cold deionized water, homogenized in a Warring blender and samples shaken on a rotary shaker for 2 hours at a speed of 200 rotations per minute and $4{ }^{\circ} \mathrm{C}$. The mixture was later centrifuged at $3000 \mathrm{~g}$ for $10 \mathrm{~min}$ at $4{ }^{\circ} \mathrm{C}$ (Eppendorf 5810R with A-4-62 swing bucket rotor). The resulting suspension was filtered through Whatman No.1 filter paper. Reducing sugar was measured using dinitrosalycilic acid reagent (Miller, 1959) and soluble protein by Bradford assay (1976).

Monosaccharides and amino acids were determined by high performance liquid chromatography (Waters e2695, USA) using a refractive index detector (Waters 2998) and a fluorescent light detector (Waters 2475), respectively. Samples for monosaccharide measurement were prepared according to Dubois et al. (1956). The calibration 
standards were mixture of glusoce, fructose, xylose and mannose. The column was COSMOSIL sugar-D and the mobile phase consisted of acetonitrile and water (80:20) with a flow rate of $0.8 \mathrm{ml} / \mathrm{min}$.

Samples for amino acids measurement were prepared using AccQ Tag Amino Acid Analysis Kit (Waters Corporation, U.S.A.) according to the manufacturer's instruction. The internal standard was $\alpha$-amino butyric acid (AABA) and the calibration standards were Standard-H (Thermo Scientific) containing the common mixture of amino acids. The column was WATERS AccQ and the mobile phase consisted of aqueous buffer and $60 \%$ acetonitrile in gradient concentrations with a flow rate of $1.0 \mathrm{ml} / \mathrm{min}$.

\subsection{Enzyme Assays}

The culture filtrate prepared above was used for measuring amylase, FPase and CMCase activities according to Fogarty and Kelly (1980), Ghose (1987) and Mandels and Weber (1974), respectively. One unit of activity was defined as the enzyme required for producing one millimole of glucose per minute.

\subsection{Statistical Analysis}

The effects of fermentation conditions on $R$. oligosporus activities were analysed by a one-way analysis of variance (ANOVA) and means comparison using the least significant differences (LSD), by using the GLM procedure of SAS (SAS, 2004). The results were presented as the mean \pm standard deviation values of three replicates. Probability values less than 0.05 were considered significant.

\section{Results}

\subsection{Optimised Fermentation Condition in $500 \mathrm{ml}$ Erlenmeyer Flask}

The highest concentration of reducing sugar was produced at $55 \mathrm{ml}$ liquid/50 g GSP (Figure 1a). The soluble protein concentrations increased significantly $(P<0.05)$ when additional moisture was available in the substrate. Amylase and CMCase activities were higher at lower moisture level but FPase activity was not affected by changes in the moisture levels (Figure 1b). Based on the results, moisture level of $55 \mathrm{ml}$ liquid/50 g GSP was selected for the subsequent experiments. 

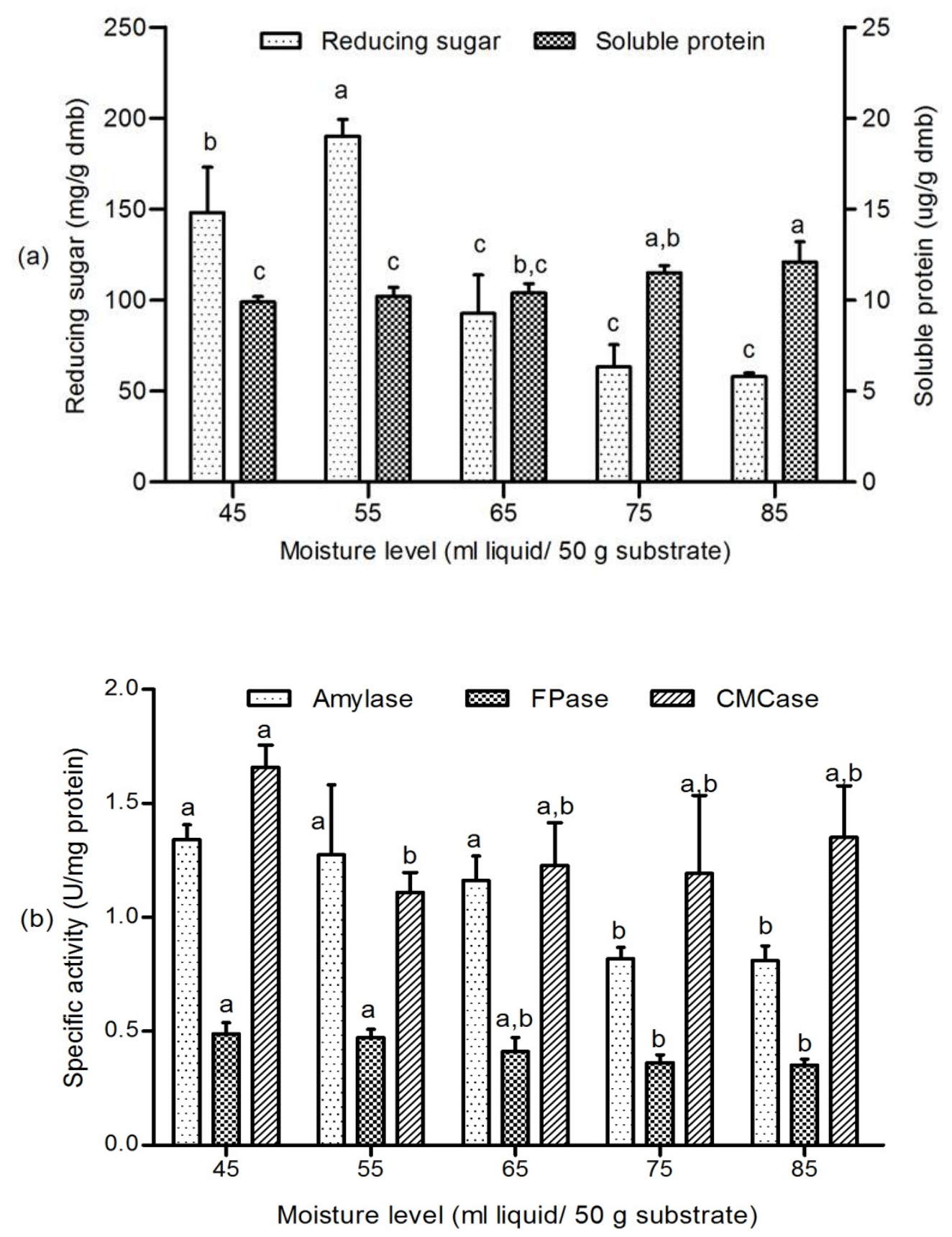

Figure 1. (a) Reducing sugar and soluble protein content (b) Amylase, FPase and CMCase activities in fermented GSP at different levels of initial moisture content

Error bar indicates standard deviation. Means with different letters are significantly different $(P<0.05)$.

The effect of incubation temperatures showed the highest concentration of reducing sugar was produced at ambient temperature $\left(28 \pm 2{ }^{\circ} \mathrm{C}\right)$, but at this temperature, the soluble protein was lower than the other incubation temperatures (Figure 2a). Amylase, FPase and CMCase were maximum when fermentation was conducted at ambient temperature or $30{ }^{\circ} \mathrm{C}$ (Figure $2 \mathrm{~b}$ ) but differences between these two temperatures were insignificant $(P>0.05)$. Hence, subsequent experiments were conducted at $30^{\circ} \mathrm{C}$. 

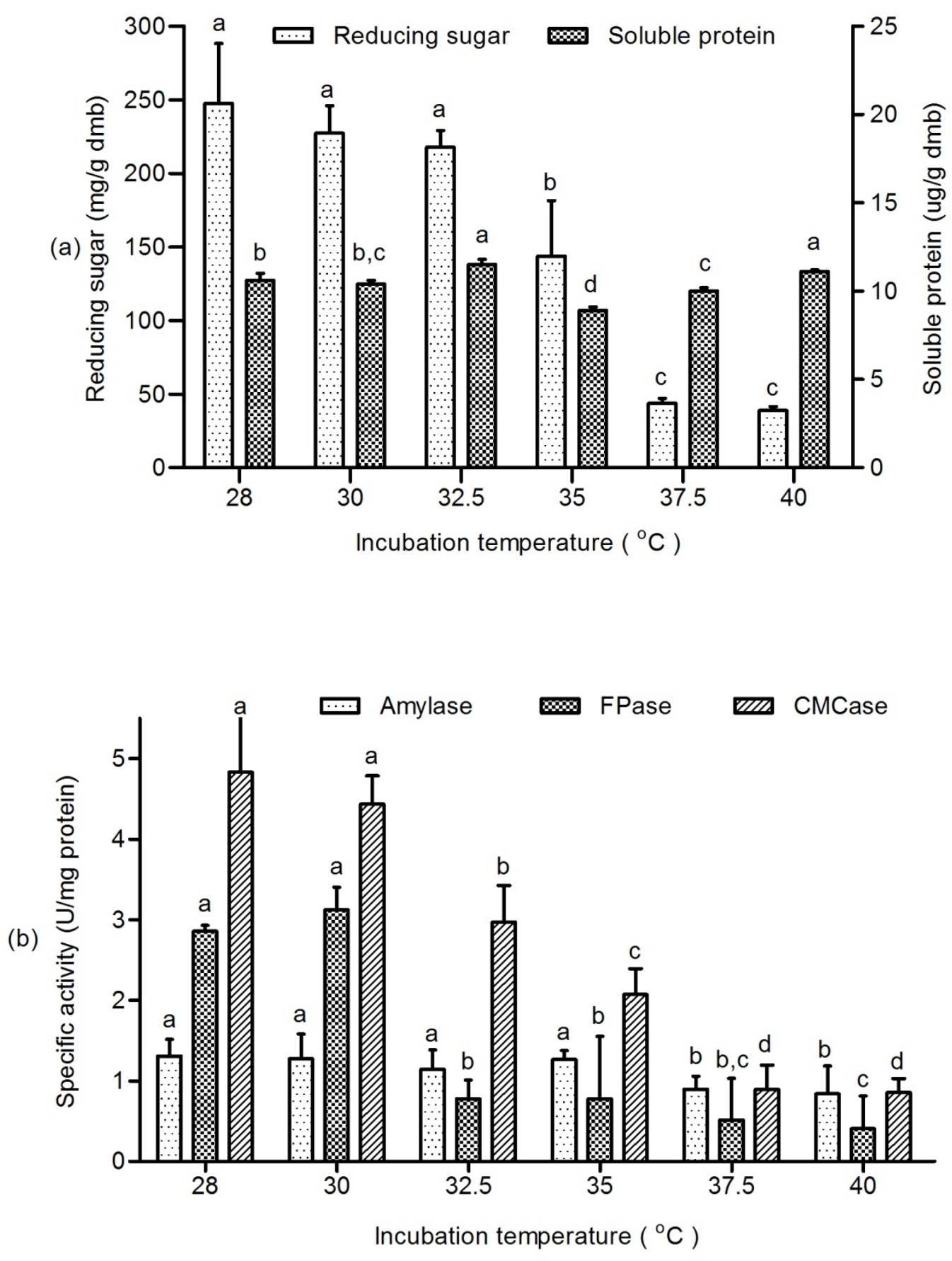

Figure 2. (a) Reducing sugar and soluble protein content (b) Amylase, FPase and CMCase activities in fermented GSP at different incubation temperatures and $55 \mathrm{ml}$ liquid/50 gm substrate moisture

Error bar indicates standard deviation. Means with different letters are significantly different $(P<0.05)$.

Different initial $\mathrm{pH}$ values did not affect significantly $(P>0.05)$ the concentration of reducing sugar but soluble protein was affected (Figure 3a). Amylase activity was higher at alkaline $\mathrm{pH}$ but FPase and CMCase activities were not affected by $\mathrm{pH}$ variations (Figure 3b). $\mathrm{pH} 6.0$ was then selected for the next set of experiment considering the soluble protein concentration in relation to other parameters measured and it is the median value between acidic and alkaline $\mathrm{pH}$. 

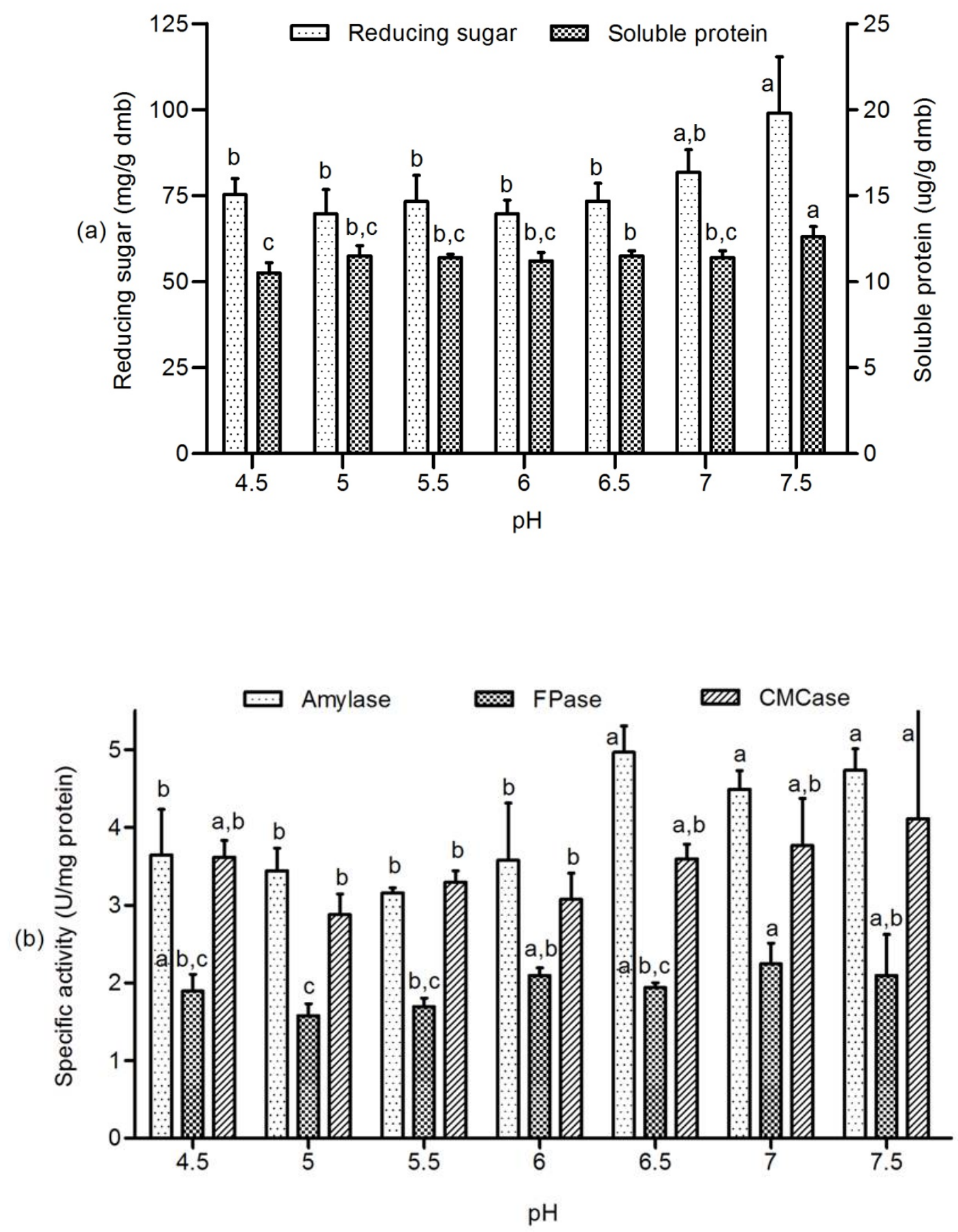

Figure 3. (a) Reducing sugar and soluble protein content (b) Amylase, FPase and CMCase activities in fermented GSP at different initial $\mathrm{pH}, 55 \mathrm{ml}$ liquid $/ 50 \mathrm{gm}$ substrate moisture and $30^{\circ} \mathrm{C}$ incubation temperature

Error bar indicates standard deviation. Means with different letters are significantly different $(P<0.05)$.

Figure 4 shows that $R$. oligosporus responded differently to the various nitrogen sources added to the SSF system. GSP supplemented with $\left(\mathrm{NH}_{4}\right)_{2} \mathrm{SO}_{4}, \mathrm{NH}_{4} \mathrm{CO}_{3}$ and $\mathrm{NH}_{4} \mathrm{MO}_{3}$ showed higher reducing sugar compared to the other nitrogen sources (Figure 4a). GSP containing $\mathrm{NH}_{4} \mathrm{CO}_{3}$ also resulted in high soluble protein but activities of hydrolytic enzymes were maximum only in substrate supplemented with $\left(\mathrm{NH}_{4}\right)_{2} \mathrm{SO}_{4}$ (Figure $4 \mathrm{~b}$ ). It was concluded that $\left(\mathrm{NH}_{4}\right)_{2} \mathrm{SO}_{4}$ was the most suitable nitrogen source. 

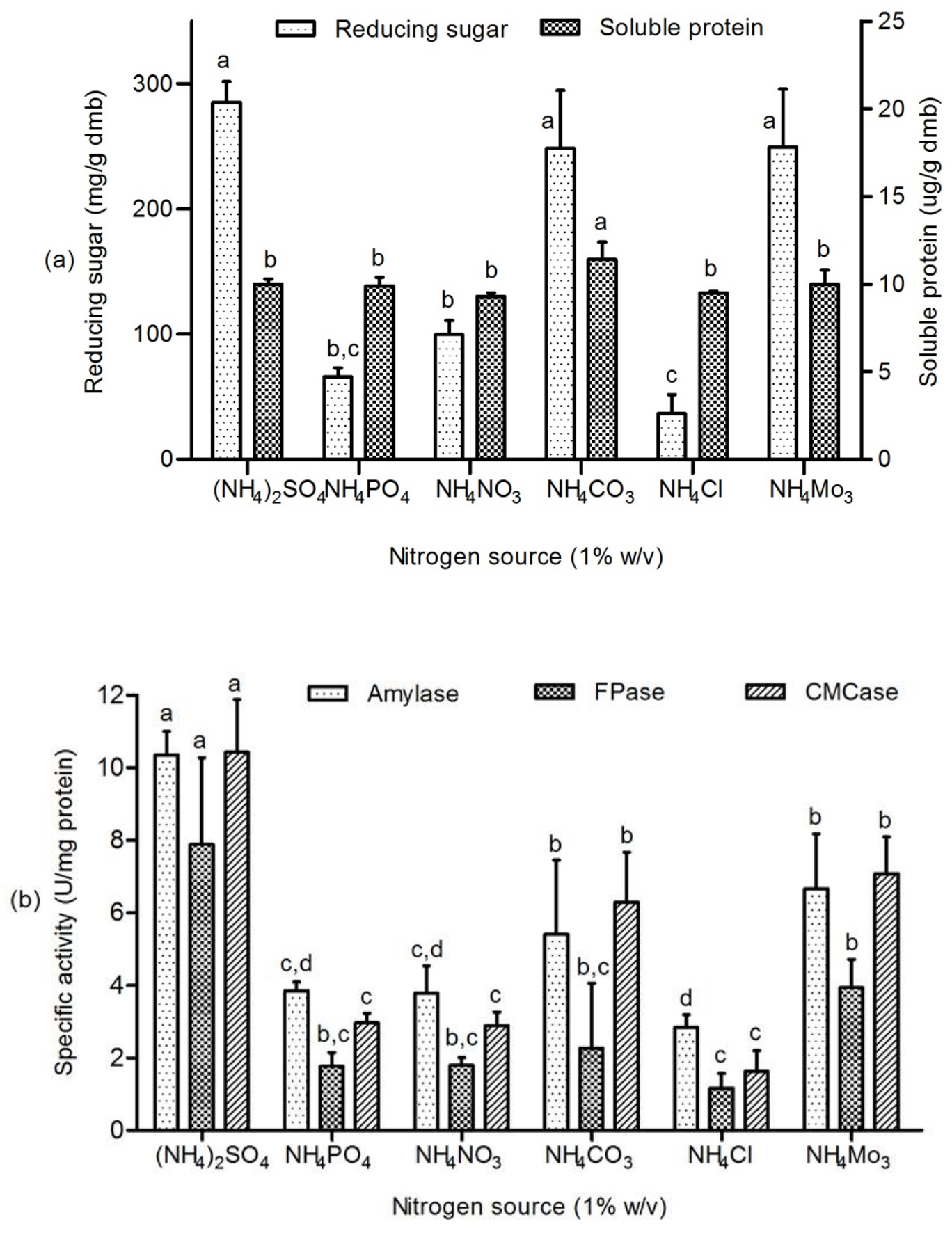

Figure 4. (a) Reducing sugar and soluble protein content (b) Amylase, FPase and CMCase activities in fermented GSP at different source of nitrogen, $55 \mathrm{ml}$ liquid/ $/ 50 \mathrm{gm}$ substrate moisture, $30^{\circ} \mathrm{C}$ incubation temperature and initial $\mathrm{pH}$ of 6.0 Error bar indicates standard deviation. Means with different letters are significantly different $(P<0.05)$

The above experiments demonstrated that optimum conditions for GSP solid state fermentation with $R$. oligosporus in $500 \mathrm{ml}$ flask system were at initial moisture $55 \mathrm{ml} / 50 \mathrm{~g}$ substrate, incubation temperature of $30{ }^{\circ} \mathrm{C}$, initial $\mathrm{pH}$ at $\mathrm{pH} 6.0 \mathrm{using} 0.01 \mathrm{M}$ citrate buffer and inorganic nitrogen source of $1 \%(\mathrm{w} / \mathrm{v})\left(\mathrm{NH}_{4}\right)_{2} \mathrm{SO}_{4}$.

\subsection{Time Course Study at Optimized Fermentation Conditions}

A time course study for 7 days at these optimized conditions showed the reducing sugar increased from $15.7 \pm 0.5$ $\mathrm{mg} / \mathrm{g}(\mathrm{dmb})$ and reached maximum value of $183.8 \pm 22.6 \mathrm{mg} / \mathrm{g}(\mathrm{dmb})$ at 1.5 days (Figure $5 \mathrm{a})$. At longer 
fermentation period, the concentration of reducing sugar decreased. Soluble protein increased gradually with fermentation time up to 7 days. Amylase and CMCase activities were highest at 3 days of fermentation; 3.580 .73 \pm and $4.44 \pm 1.50 \mathrm{U} / \mathrm{mg}$ protein, respectively. However, FPase activities did not show any apparent changes during the fermentation (Figure 5b). The temperature showed a rapid increase between 0.5 days and 1.5 days (Figure $5 \mathrm{c}$ ). At this point, the temperature was maximum $\left(34^{\circ} \mathrm{C}\right)$ but later decreased to $30{ }^{\circ} \mathrm{C}$ and remained constant until the end of fermentation. $\mathrm{pH}$ of the fermented substrate dropped by more than $2 \mathrm{pH}$ units at the end of fermentation from the initial $\mathrm{pH}$ of $6.09 \pm 0.22$ to $3.97 \pm 0.09$.
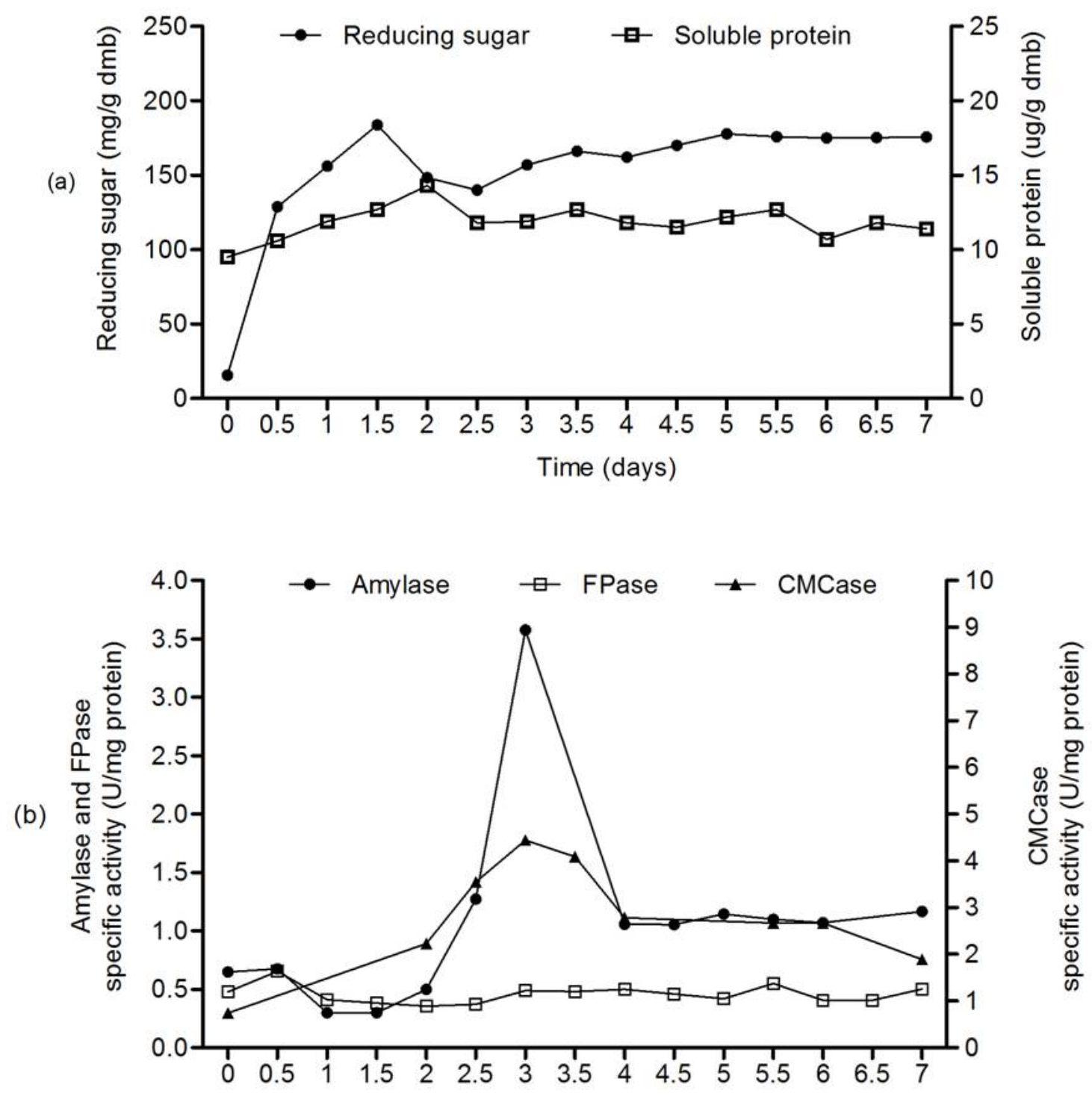

Time (days) 


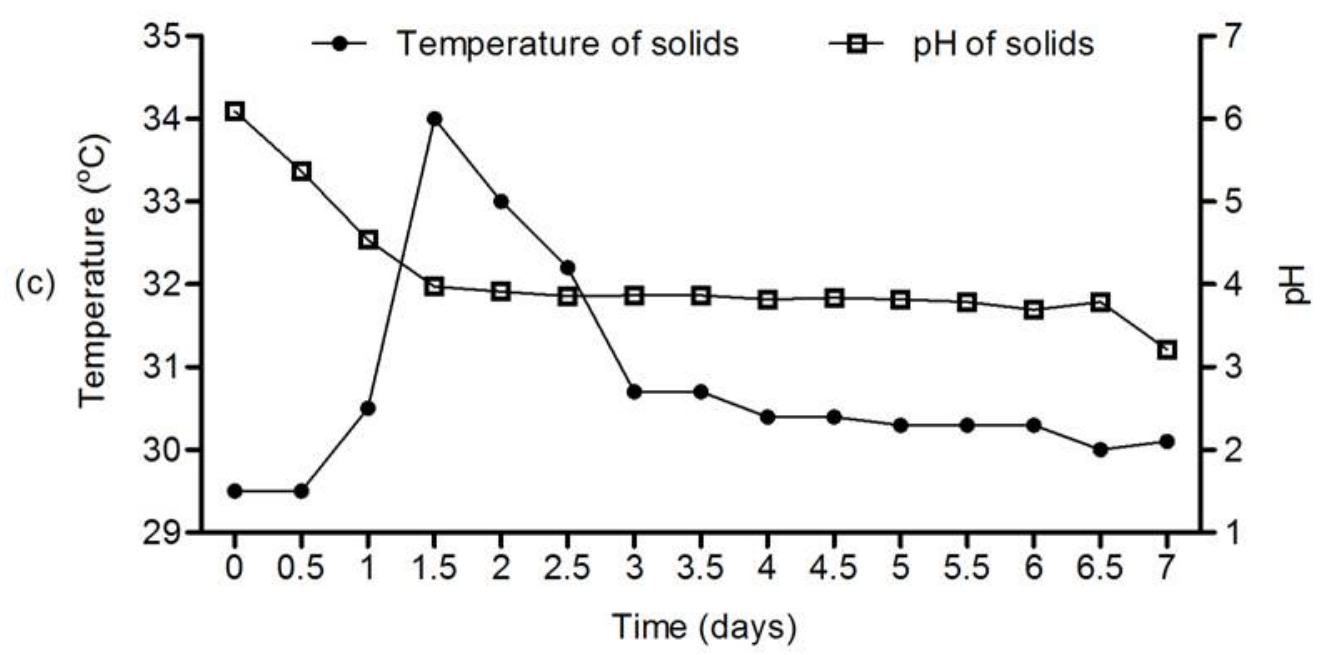

Figure 5. (a) Reducing sugar and soluble protein content (b) Amylase, FPase and CMCase activities (c) Internal temperature and $\mathrm{pH}$ of fermented GSP at optimized conditions for 7 days

\subsection{Nutrient Compositions of Untreated and Fermented GSP}

The nutrient compositions of untreated (UGSP) and fermented GSP (FGSP) are presented in Table 1. The dry matter, crude protein and ash in FGSP were increased but crude fibre and gross energy were decreased. Reducing sugar and soluble protein in the aqueous extract of FGSP were increased by more than 100 percent and the $\mathrm{pH}$ was reduced by more than $2 \mathrm{pH}$ units from $5.42 \pm 0.23$ to $3.02 \pm 0.02$.

Table 1. Proximate composition, reducing sugar and soluble protein of untreated and fermented GSP produced in laboratory fermenter

\begin{tabular}{lllll}
\hline Composition & UGSP & FGSP & \% increament or reduction & Corn meal \\
\hline Proximate analysis: & & & & \\
Dry matter, \% & 88.2 & 89.1 & increased by $1.0 \%$ & 89 \\
Crude protein, \% & 1.6 & 3.4 & increased by $>100 \%$ & 8.5 \\
Crude fibre, \% & 6 & 5.5 & reduced by $9.1 \%$ & 2.2 \\
Ash, \% & 5.3 & 6.3 & increased by $18.9 \%$ & 4 \\
Gross energy, cal $/ \mathrm{kg}$ & 3608 & 3495 & reduced by $3.2 \%$ & 3350 \\
Aquaeous extract: & & & & \\
Reducing sugar, $\mathrm{mg} / \mathrm{g}(\mathrm{dmb})$ & $285.4 \pm 3.35$ & $736.4 \pm 23.52$ & increased by $>100 \%$ & \\
Soluble protein, $\mu \mathrm{g} / \mathrm{g}(\mathrm{dmb})$ & $1.4 \pm 0.17$ & $9.1 \pm 0.11$ & increased by $>100 \%$ & \\
pH of wet solids & $5.42 \pm 0.23$ & $3.02 \pm 0.02$ & reduced by $79 \%$ & \\
\hline
\end{tabular}

UGSP untreated ground sago pith; FGSP fermented ground sago pith.

$\mathrm{g}(\mathrm{dmb})=$ gram $($ dry matter basis $)$. Values are mean \pm standard deviation.

*Corn meal as comparison (NRC, 1994).

Monosaccharides detected in both UGSP and FGSP were xylose, fructose, mannose and glucose but the percentage of fructose and glucose in FGSP had increased remarkably (Table 2). Amino acids profiles are presented in Table 3. Cysteine which was undetected in the unfermented GSP was produced during the fermentation at a concentration of $222 \mathrm{ppm}$. The other amino acids were increased by $1.5 \%$ (arginine), $2.1 \%$ 
(glutamic acid), 16.2\% (isoleucine), 16.5\% (leucine), 6.2\% (phenylalanine), 25.7\% (proline), 38.2\% (serine), $27.3 \%$ (threonine)and $5.7 \%$ (tyrosine).

Table 2. Monosaccharides concentration of untreated and fermented GSP produced in laboratory fermenter

\begin{tabular}{llll}
\hline Monosaccharides & $\begin{array}{l}\text { UGSP } \\
{[\mathrm{mg} / \mathrm{g}(\mathrm{dmb})]}\end{array}$ & $\begin{array}{l}\text { FGSP } \\
{[\mathrm{mg} / \mathrm{g}(\mathrm{dmb}]}\end{array}$ & $\%$ increament \\
\hline Xylose & 0.02 & 0.1 & 80 \\
Fructose & 0.38 & 5.32 & $>100$ \\
Mannose & 0.12 & 0.14 & $<1$ \\
Glucose & 0.47 & 5.77 & $>100$ \\
\hline
\end{tabular}

UGSP, untreated ground sago pith; FGSP, fermented ground sago pith.

Table 3. Amino acids concentration of untreated and fermented GSP produced in laboratory fermenter.

\begin{tabular}{|c|c|c|c|}
\hline Amino acids & $\begin{array}{l}\text { UGSP } \\
(\mathrm{ppm})\end{array}$ & $\begin{array}{l}\text { FGSP } \\
(\mathrm{ppm})\end{array}$ & $\begin{array}{l}\% \\
\text { increament }\end{array}$ \\
\hline \multicolumn{4}{|c|}{ Essential amino acids } \\
\hline Cysteine & n.d. & 222 & - \\
\hline Threonine & 1143 & 1572 & 27.3 \\
\hline Isoleucine & 31 & 37 & 16.2 \\
\hline Leucine & 637 & 764 & 16.5 \\
\hline Phenylalanine & 30 & 32 & 6.2 \\
\hline Tyrosine & 727 & 771 & 5.7 \\
\hline Lysine & n.d. & n.d. & - \\
\hline Methionine & n.d. & n.d. & - \\
\hline Valine & n.d. & n.d. & - \\
\hline Histidine & n.d & n.d. & - \\
\hline \multicolumn{4}{|c|}{ Non essential amino acids } \\
\hline Serine & 147 & 238 & 38.2 \\
\hline Proline & 133 & 179 & 25.7 \\
\hline Glutamic acid & 3199 & 3269 & 2.1 \\
\hline Arginine & 3231 & 3279 & 1.5 \\
\hline Alanine & n.d. & n.d. & - \\
\hline Asparagine & n.d. & n.d. & - \\
\hline Aspartic acid & n.d. & n.d. & - \\
\hline Glycine & n.d. & n.d. & - \\
\hline Hydroxyproline & n.d. & n.d. & - \\
\hline Tryptophane & n.d. & n.d. & - \\
\hline
\end{tabular}

UGSP, untreated ground sago pith; FGSP, fermented ground sago pith.

n.d. $=$ not detected i.e. the values were lower than the detection limit $(<10 \mathrm{ppm})$. 


\section{Discussion}

\subsection{Optimization of SSF Conditions}

The main factors that influenced the behavior of microorganisms in solid state conditions include water activity and moisture, temperature, $\mathrm{pH}$, aeration, bed properties and nature of solid substrates employed (Singhania et al., 2009). In the current study, GSP moistened with $55 \mathrm{ml}$ liquid/50 g substrate provided an optimum level for fungal growth and enzyme activities. In general, fungal cultures required low moisture level (20 to $70 \%)$ compared to the requirement of a bacterial culture, which is higher than $70 \%$ (Gowthaman et al., 2001). Very high moisture caused substrate compaction thus limiting nutrient transfer and gas diffusion between the substrate particles. An appropriate combination of the substrate moisture and the incubation temperature is necessary in fungal SSF. Results of this study showed the moisture level of $55 \mathrm{ml}$ liquid/50 g GSP and incubation temperature of $30{ }^{\circ} \mathrm{C}$ produced maximum growth.

This study also indicated that $R$. oligosporus growth was not significantly affected by acidic or alkaline $\mathrm{pH}$. The results were in agreement with previous studies by Nagel et al. (1999) and Sparinga et al. (2002) on the effect of $\mathrm{pH}$ using several buffering agent on the growth of $R$. oligosporus in SSF system. There were no significant difference in biomass produced between $\mathrm{pH} 4$ and $\mathrm{pH} 7$ but the optimum growth occurred at acidic $\mathrm{pH}$ below 6 , provided by the citric acid buffer. A slightly acidic $\mathrm{pH}$ and lower moisture ratio offer an advantage in reducing the risk of bacterial contamination, since bacteria are unable to grow at low moisture level and acidic $\mathrm{pH}$ (Gowthaman et al., 2001).

Exogenous nitrogen added to SSF substrate balanced the carbon and nitrogen ratio to support growth and hydrolytic activities of filamentous fungi. The results showed that growth of $R$. oligosporus began on the first day of incubation and maximum enzyme activities were observed in GSP containing ammonium sulphate. Sulphur ions are essentials in fungal physiology and sulphate, the oxidized state of inorganic sulphur is the most common source supplied to the culture medium for fungi. Ammonium sulphate was reported to influence the level of protein and biomass production in SSF aimed for protein enrichment of rice bran using $R$. oryzae (Schmidt \& Furlong, 2012) and food processing waste using R. arrhizus and $R$. oryzae (Jin et al.,2005).

\subsection{SSF at Optimized Condition}

Substrate utilization and the growth related activities of $R$. oligosporus in GSP at optimized conditions were represented by the production of reducing sugar, soluble protein, hydrolytic activities and changes in the internal temperature and $\mathrm{pH}$ of the solid substrate. An optimum fermentation rate could have occurred between 1.5 to 3 days of incubation as indicated by the maximum amount of reducing sugar and the related amylase and CMCase activities. The enzyme activities increased with time during fermentation and reached maximum values at 3 days. Similar observation was reported by Rashid et al. (2003) on filamentous fungi cultivation in palm oil mill effluent as a basal medium. The highest CMCase activities were detected after 3 to 5 days of fermentation.

The rapid temperature rise at the fermenting substrate was the result of metabolic heat generated from fungal growth. However, inefficient heat removal after reaching the maximum temperature may result in declining metabolic activity. Although the soluble protein increased, the fermentation slowed down with declining $\mathrm{pH}$ values. The lowering of $\mathrm{pH}$ was the result of organic acids production. Rhizopus $\mathrm{sp}$. is known to produce organic acids such as lactic acids (Jin et al., 2005; Zhang et al., 2007) and fumaric acids (Liao et al., 2007) from the starch components in the substrate. Bioconversion into organic acids occur simultaneously from saccharification of starch that produce sugar and fermentation of sugar to lactic or fumaric acids.

\subsection{NutrientComposition of Untreated and Fermented GSP}

Fermentation is characterized by the conditions offered by a particular substrate for microbial growth and the changes in the substrate condition as a result of interactions between hydrolysis and products formed. Proximate analysis of FGSP showed higher percentage of dry matter, crude protein and ash. The dry matter and ash of FGSP had increased by $1 \%$ and $18.9 \%$, respectively. This is in accordance with a study by Oduguwa et al. (2008). An increase up to $30 \%$ in ash content was observed after 120 hours of $R$. oligosporus SSF on corn cob, rice bran and cowpea husk. The crude protein of GSP showed an increase of more than 100 percent, from $1.6 \%$ in UGSP to $3.4 \%$ in FGSP. Crude protein increment has been demonstrated in Rhizopus SSF aimed for protein enrichment. Schmidt and Furlong (2012) reported a protein level of $20 \mathrm{~g} / 100 \mathrm{~g}$ of dry weightin the presence of $8 \mathrm{~g} / \mathrm{L}$ ammonium sulphate. Meanwhile, the crude fibre and gross energy had decreased, indicating some degree of degradation had taken place. The decrease of crude fibre was also reported by Pal Vig and Walia (2001) on fermented rapeseed meal using $R$. oligosporus. Fungal SSF generally reduced crude fibre content of agricultural feedstuffs because of the fungal ability to produce cellulase enzymes and the hyphael mode of growth. 
High percentage of reducing sugar and monosaccharides in FGSP indicated that $R$. oligosporus was actively utilizing starch as this is the major component in GSP readily available to the fungus. The changes were associated with hydrolytic activities especially amylase and CMCase that were considerably high when GSP was supplemented with $1 \%(\mathrm{w} / \mathrm{v})$ of ammonium sulphate (Figure $4 \mathrm{~b})$. Glucose and fructose amount in FGSP produced in fermenter increased by more than 100 percent. A study by Olanipekun et al. (2009) showed that starch and amylose content in extracts from soybean flour were reduced after 72 hours of SSFby $R$. oligosporus. A mixture of high and low molecular weight carbohydrates; fructose, glucose, xylose, inositol, cellobiose, galacturonic acid oligomers and polysaccharides, was produced in R. nigricans SSF on lemon peel as a result of hydrolysis (Hellín et al., 2001).

A small amount of xylose was produced (Table 2) as a result of hemicellulose depolymerization. The production was related to CMCase activity as demonstrated from the optimized conditions of fermentation in flask system (Figure $4 \mathrm{~b}$ ). The effect of CMCase could also be detected as indicated by the reduction of crude fiber in FGSP produced in the fermenter. A synergy amongst starch and fibre degrading enzymes were necessary to degrade GSP into digestible components. Meng and Slominski (2005) reported that treatment of corn, soybean meal, canola meal, and peas aimed for broiler feed using multicarbohydrase enzymes affected the nutritive values through degradation of the cell wall components and increasing starch availability.

The amino acids profiles indicated that SSF of GSP by R. oligosporus produced cysteine and increased threonine, isoleucine, leucine, phenylalanine, tyrosine, serine, proline, glutamic acid and arginine contents (Table 3 ) by 1.5 to $38.2 \%$. The changes could be related to increment of soluble protein produced by the fungal activities (Table 1). Amino acids are metabolites produced during fungal SSF as a consequence of protein hydrolysis and synthesis related to growth. In SSF process of cactus pulp using Aspergillus niger, the principal amino acids produced were aspartic acids, threonine, glutamic acid, valine, serine, arginine and phenylalanine (Oliveira et al., 2001).

\section{Conclusion}

Solid state fermentation using $R$. oligosporus improved the nutritive value of GSP by increasing the reducing sugar by $61 \%$, glucose and fructose by more than $100 \%$, soluble protein by $1 \%$, amino acids by 1.5 to $38.2 \%$ and producing cysteine at $222 \mathrm{ppm}$.

\section{Acknowledgement}

This project was funded by the Malaysian Ministry of Agriculture, Putrajaya, Malaysia, through the AgriScience Fund no. 05-01-04-SF1031.

\section{References}

Association of Analytical Chemists, AOAC. (1990). Official Methods of Analysis (15th ed.), AOAC, Washington, DC, USA.

Bradford, M. (1976). A rapid and sensitive method for the quantification of microgram quantities of protein utilizing the principle of protein-dye binding. Annals of Biochemistry, 72, 248-254. http://dx.doi.org/10.1016/0003-2697 (76)90527-3

Chen, L., Madl, R., \& Vadlani, P. V. (2013). Nutritional enhancement of soy meal via Aspergillus oryzae solid state fermentation. Cereal Chemistry, 90(6), 529-534. http://dx.doi.org/10.1094/CCHEM-01-13-0007-R

Department of Statistics Malaysia. (2005). Sarawak Export of Sago Starch, SITC Code:592-150-100. Department of Statistics, Kuala Lumpur, Malaysia.

Dubois, M., Gilles, K. A., Hamilton, J. K., Rebers, P. A., \& Smith, F. (1956). Colorimetric method for determination of sugars and related substances. Analytical Chemistry, 28, 350-356. http://dx.doi.org/10.1021/ac60111a017

Fogarty, W. M., \& Kelly, C. (1980). Amylase, amyloglucosidase and related gluconases. In A. H. Rose (Ed.) Microbial Enzymes and Bioconversions Economic Microbiology. Volume 5. Academic Press, London, UK.

Ghose, T. K. (1987). Measurement of cellulase activities. Pure and Applied Chemistry, 59(2), 257-268. http://dx.doi.org/10.1351/pac198759020257

Gowthaman, N. K., Krishna, C., \& Mou-Young, M. (2001). Fungal solid state fermentation - an overview. In G. G. Khachatourians \& D. K. Arora (Eds.). Applied Mycology and Biotechnology. Volume I. Agriculture and Food Production. Elsevier Science, B.V.

Grossman, R. B., \& Reinsch, T. G. (2002). SSSA Book Series: 5.Methods of Soil Analysis. In J. H. Dane, Clarke Topp, G. (Eds). Soil Science Society of America, Inc. Madison, Wisconsin. 
Harris, L. E., Asplund, J., \& Crampton, E. W. (1968). An international feed nomenclature and methods for summarizing and using feed data to calculate diets. Utah State University Agricultural Experiment Station Bulletin No. 479.

Hellín, P., Ros, J. M., \& Laencina, J. (2001). Changes in high and low molecular weight carbohydrates during Rhizopusnigricans cultivation on lemon peel. Carbohydrate Polymers, 45, 169-174. http://dx.doi.org/10.1016/S0144-8617(00)00317-9

Hotz, C., \& Gibson, R. S. (2007). Traditional food-processing and preparation practices to enhancing the bioavailability of micronutrients in plant-based diets. Journal of Nutrition, 137, 1097-1100.

Jin, B., Yin, P., Ma, Y., \& Zhao, L. (2005). Production of lactic acid and fungal biomass by Rhizopus fungi from food processing waste stream. Journal of Industrial Microbiology \& Biotechnology, 3, 678-686. http://dx.doi.org/10.1007/s10295-005-0045-4

Karim, A., Pei-Lang, A., Manan, D., \& Zaidul, I. (2008). Starch from the Sago (Metroxylon sagu) palm trees Properties, prospects and challenges as a new industrial source for food and other sources. Comprehensive Review in Food Science and Food Safety, 7, 215-227. http://dx.doi.org/10.1111/j.1541-4337.2008.00042.x

Liao, W., Liu, Y., \& Chen, S. (2007). Studying pellet formation of a filamentous fungus Rhizopus oryzae to enhance organic acid production. Applied Biochemistry and Biotechnology, 137, 689-701. http://dx.doi.org/10.1007/ s12010-007-9089-4

Mandels, M., \& Weber, J. (1974). Measurement of saccharifying cellulose. Journal of Advances in Chemical Series, 95, 391. http://dx.doi.org/10.1021/ba-1969-0095.ch023

Meng, X., \& Slominski, B. A. (2005). Nutritive values of corn, soybean meal, canola meal, and peas for broiler chickens as affected by a multicarbohydrase preparation of cell wall degrading enzymes. Poultry Science, 84, 1242-1251. http://dx.doi.org/10.1093/ps/84.8.1242

Miller, G. L. (1959). Use of dinitrosalicylic acid reagent for determination of reducing sugar. Analytical Chemistry 31(3), 426-428. http://dx.doi.org/10.1021/ac60147a030

Nagel, F., Oostra, J., Tramper, J., \& Rinzema, A. (1999). Improved model system for solid-substrate fermentation: effects of $\mathrm{pH}$, nutrients and buffer on fungal growth rate. Process Biochemistry, 35, 69-75. http://dx.doi.org/10.1016/S0032-9592(99)00034-5

National Research Council, NRC. (1994). Nutrient Requirements of Poultry. Ninth revised edition. Washington, DC, USA: National Academy Press.

Nout, M. J. R., \& Kiers, J. L. (2005). Tempe fermentation, innovation and functionality: update into the third $\begin{array}{lllll}\text { millenium. Journal of } & \text { Applied }\end{array}$ http://dx.doi.org/10.1111/j.1365-2672.2004.02471.x

Oduguwa, O. O., Edema, M. O., \& Ayeni, A. O. (2008). Physico-chemical and microbiological analyses of fermented corn cob, rice bran and cowpea husk for use in composite rabbit feed. Bioresource Technology, 99, 1816-1820. http://dx.doi.org/10.1016/j.biortech.2007.03.036

Olanipekun, B. F., Otunola, E. T., Adelakun, O. E., \& Oyelade, O. J. (2009). Effect of fermentation with Rhizopusoligosporus on some physico-chemical properties of starch extracts from soybean flour. Food and Chemical Toxicology, 47, 1401-1405.http://dx.doi.org/10.1016/j.fct.2009.02.023

Oliveira, M. A., Rodrigues, C., dos Reis, E. M., \& Nozaki, J. (2001). Production of fungal protein by solid substrate fermentation of cactus Cereus peruvianus and Opuntia ficus indica. Quimica Nova, 24(3), 307-310. http://dx.doi.org/10.1590/s0100-40422001000300004

Pal Vig, A., \& Walia, A. (2001). Beneficial effects of Rhizopus oligosporus fermentation on reduction of glucosinolates, fibre and phytic acid in rapeseed (Brassica napus) meal. Bioresource Technology, 78, 309-312. http://dx.doi.org/10.1016/S0960-8524(01)00030-X

Schmidt, C. G., \& Furlong, E. B. (2012). Effect of particle size and ammonium sulfate concentration on rice bran by fermentation with the fungus Rhizopus oryzae. Bioresource Technology, 123, 36-41. http://dx.doi.org/10.1016/j.biortech.2012.07.081

Rashid, S. S., Alam, M. Z., Karim, M. I. A., \& Salleh, M. H. (2009). Management of palm oil mill effluent through production of cellulases by filamentous fungi. World Journal of Microbiology and Biotechnology, 25, 2219-2226. http://dx.doi:10.1007/s11274-009-0129-9 
Singhal, R., Kennedy, J., Gopalakrishnan, S., Kaczmarek, A., Knill, C., \& Akmar, P. (2008). Industrial production, processing, and utilization of sago palm-derived products. Carbohydrate Polymers, 72, 1-20. http://dx.doi.org/10.1016/j.carbpol.2007.07.043

Singhania, R., Patel, A., Soccol, C., \& Pandey, A. (2009). Recent advances in solid state fermentation. Biochemical Engineering Journal, 44, 13-18. http://dx.doi.org/10.1016/j.bej.2008.10.019.

Sparinga, R. A., Kendall, M., Westby, A., \& Owens, J. D. (2002). Effects of temperature, pH, water activity and $\mathrm{CO}_{2}$ concentration on growth of Rhizopus oligosporus NRRL 2710. Journal of Applied Microbiology, 92, 329-337. http://dx.doi.org/10.1046/j.1365-2672.2002.01534.x

Statistical Analytical System. (2002). SAS user's guide: statistics. SAS Inst. Inc., Cary, NC, USA.

Teng, D., Gao, M., Yang, Y., Liu, B., Tian, Z., \& Wang, J. (2012). Bio-modification of soybean meal with Bacillus subtilis or Aspergillus oryzae. Biocatalysis and Agricultural Biotechnology, 1, 32-38. http://dx.doi.org/10.1016/j.bcab.2011.08.005

Yahya, M., Mahyuddin, M., Alimon, A. R., Abdullah, N., \& Ivan, M. (2011). Sago pith meal based diets in sheep containing different sources of nitrogen: Feed preparation, growth performance, digestibility and carcass $\begin{array}{lllll}\text { quality. Animal Feed Science and Technology, } & \text { 170, }\end{array}$ http://dx.doi.org/10.1016/j.anifeedsci.2011.08.009

Zhang, Z. Y., Jin, B., \& Kelly, J. M. (2007). Production of lactic acid from renewable materials by Rhizopus fungi: Mini review. Biochemical Engineering Journal, 35, 251-263. http://dx.doi.org/ 10.1016/j.bej.2007.01.028

\section{Copyrights}

Copyright for this article is retained by the author(s), with first publication rights granted to the journal.

This is an open-access article distributed under the terms and conditions of the Creative Commons Attribution license (http://creativecommons.org/licenses/by/3.0/). 